Article

\title{
Does Corporate Social Responsibility Vary by Real Estate Asset Types? Evidence from Real Estate Investment Trusts
}

\author{
Jian Liang ${ }^{1, * \mathbb{D}}$, Ameeta Jain ${ }^{1}$ and Hao $\mathrm{Wu}^{2}{ }^{2}$ \\ 1 Department of Finance, Faculty of Business and Law, Deakin University, Geelong, VIC 3220, Australia; \\ ameetaj@deakin.edu.au \\ 2 Faculty of Architecture, Building and Planning, The University of Melbourne, \\ Melbourne, VIC 3010, Australia; haow@unimelb.edu.au \\ * Correspondence: jerry.liang@deakin.edu.au
}

Citation: Liang, J.; Jain, A.; Wu, H. Does Corporate Social Responsibility Vary by Real Estate Asset Types? Evidence from Real Estate Investment Trusts. Sustainability 2021, 13, 12836 https://doi.org/10.3390/su132212836

Academic Editor: Ioannis Nikolaou

Received: 2 November 2021

Accepted: 17 November 2021

Published: 19 November 2021

Publisher's Note: MDPI stays neutral with regard to jurisdictional claims in published maps and institutional affiliations.

Copyright: (c) 2021 by the authors. Licensee MDPI, Basel, Switzerland. This article is an open access article distributed under the terms and conditions of the Creative Commons Attribution (CC BY) license (https:// creativecommons.org/licenses/by/ $4.0 /)$.

\begin{abstract}
This paper investigates how real estate investment trusts' corporate social responsibility (CSR) (REITs) varies by two intrinsic firm factors: real estate asset types and REITs' financial aspirations. We develop a conceptual model to demonstrate the theoretical role of these intrinsic firm factors in moderating CSR. Using a database containing the Morgan Stanley Capital International CSR rating index, we test REITs from 19 countries for variations of their CSR performance across each of the three pillars of CSR: environment, social, and governance (ES\&G) by real estate asset types from 2009 to 2016. The results show that REITs focusing on less market-transparent real assets relying heavily on intensive human-based services and physical capital in property management like hotels and hospitals exhibit a poorer performance in environmental responsibility, social responsibility, and overall CSR score. We found no significant difference between the REITs in their governance responsibility with respect to the real estate asset types. We found that moderation by financial aspiration in establishing their CSR strategies varies by the types of real estate asset that REITs focus on, with the maximum positive impact on REITS with hotel holdings and negative impact on REITs with office and retail assets.
\end{abstract}

Keywords: CSR; REITs; asset type; financial aspiration

\section{Introduction}

Corporate Social Responsibility (CSR) reflects the economic, legal, ethical, and discretionary responsibilities of a firm [1]. However, measuring these values across any firm is difficult, necessitating assessing the firm's "engagement in and compliance with environmental, social and traditional governance issues" [2], using proprietary and academic measurement tools. An example of such a database is the Environmental Social and Governance Index (ESGI), developed by Morgan Stanley Capital International (MSCI), which measures and rates the CSR performance of business firms from around the world across the three pillars of CSR: Environment (E), Social (S) and Governance (G)-the ES\&G. As a firm's behavior and performance face constraints of fundamental factors such as their asset and managerial characteristics, it is reasonable to consider that these factors can influence its CSR performance.

Real Estate Investment Trusts (REITs) are a popular investment vehicle specializing in real estate as a distinct asset class, which own approximately US\$3.5 trillion in gross real estate assets and provide 2.4 million jobs to the US economy in 2018 [3]. REITs are governed by specific regulatory regimes as a pass-through entity and enjoy favourable tax treatment. Their organizational structure and business model are close to unitary. As Bauer et al. [4] state, REITs "leave relatively little cash flow for management, reducing agency problems. And offer a natural experiment in corporate governance [CSR]". Therefore, REITs provide an ideal setting to investigate the differences in operational outcomes like CSR caused by 
their strategic investment focus, as heterogeneity in firm structure and management is automatically controlled.

There is an increasing body of literature on CSR and REITs: for example, Bauer, Eichholtz, and Kok [4] demonstrated that a firm's value is significantly linked to firm-level governance with low payout ratios; Brounen and Marcato [5] explored the impact of CSR ES\&G scores on REITs financial performance; other scholars reviewed the impact on CSR of board size and CEO experience [6]; presence or absence of green buildings in the portfolio [7,8]; investor interest [9]; and growth opportunities [10]. Balasubramanian et al. [11] categorically stated that firm characteristics moderate the firm's CSR. While some of the other moderating factors for CSR have been previously studied [11], the moderating impact of the specific asset types held by an investment firm such as REITs has not been studied. REIT holdings include various real estate asset types, such as retail, hospitality, office, hospital, and residential-each with unique physical, socio-economic, managerial, and legal characteristics $[3,12,13]$. Thus, the existing literature has mapped the drivers of CSR, but not some of the intrinsic firm characteristics such as asset holding type and firm's financial aspiration, which may modify the firm's CSR irrespective of the impact of the drivers of CSR. Our nuanced analysis of firm behaviour addresses this first gap in the literature by providing an improved understanding of some of CSR modifiers: asset type and financial aspiration using REITs in this exploratory study.

This paper empirically investigates how REITs' CSR performance varies by the types of real estate assets they hold and manage in response to the ES\&G criteria. It then tests how REITs' financial aspiration moderates their CSR strategy and the extent to which this moderation effect varies by real estate asset types held by REITs. We used a sample of global REITs managing different real estate asset portfolios to evaluate their performance across the ES\&G criteria. This paper extends the multi-dimension nature of REITs CSR to the asset level and finds different CSR performances for each type of real estate asset. Furthermore, the REITs focused on specific real estate asset types are moderated differently by their firm's financial aspiration in establishing their CSR strategies. We argue that real estate assets of specific types contribute to the variations of REITs CSR performance. In addition to REITs' specific demand for corporate image, portfolio asset fundamentals relevance to REITs CSR performance contributes to their investment decisions, such as portfolio construction strategy and industry governance. The results of this research will allow a nuanced understanding of REITs CSR, and by demonstrating REITs, ES\&G grading addresses the second gap in the literature. Thus, our research compares ES\&G ratings of similar asset holdings based on actual asset composition and help REITs improve their overall CSR practice and performance.

The following sections review the conceptual links of REITs CSR and real estate assets leading to our hypothesis development. This paper then briefly overviews the CSR rating system relevant to the REITs sector, allowing the development of an empirical strategy and results discussed in light of the existing theory and literature. Finally, it provides concluding remarks and the relevance of this research to practice.

\section{Recent Literature on CSR in REITs}

CSR remains in evolution from purely voluntary to legislatively mandated in different jurisdictions [14]. Examples of academic literature on CSR abound, for instance, focussing on the motivations and drivers of CSR [15], legitimacy provided by CSR [16], soft and hard regulatory focus [17,18], CEO or senior management's motivation [19], stakeholder perspective [20], the role of government [21], corporate financial performance [22] and capability and performance of the firm [23]. There is separate literature on firm characteristics that modify the drivers of CSR: firm size, transnational firms, resource availability, innovation propensity, bureaucracy, organizational inertia [11]; environmental innovation [24]; board membership, size and nature of the firm [25-28]; CEO regulatory focus [29]; customer demand [30]; and financial aspiration [31]. Chiang, Wachtel, and Zhou [10] find that the three pillars of CSR, ES\&G, are driven by separate motivations. Environmental 
CSR enabled REITs to build a competitive advantage and capitalize on growth opportunities, whereas community (social) or governance CSR is more reflective of their reponse to mandated responsibility.

CSR in REITs has progressed mainly due to investor demand for socially responsible investing, spurring on firms' appropriate disclosures in their annual and CSR reports [32]. As CSR ratings and standards are institutionalized [33], green building and asset certification and supporting regulations affect asset performance. Some studies directly evaluated REITs CSR's impact on financial performance (see for example $[4,34])$. Others, for example, Hartzell et al. [35], assessed the role of governance mechanisms by analyzing REITs' share issue and repurchase decisions and demonstrating that REITs with institutional ownership exhibit greater sensitivity to their investment opportunities. Newell et al. [36], using ES\&G ratings from Corporate Monitor, an independent research organization, found that REITs with portfolio diversification have improved ES\&G rating scores. Newell and Lee [9] demonstrate that corporate governance had the most impact of ESG factors on A-REIT CSR performance, similarly to Chiang, Wachtel, and Zhou [10]. Westermann et al. [37] calculated CSR ratings using a weighted score from REITs performance in the community, employee, environment, and governance categories from CSRHub. They did not separtely analyse the ES\&G components. Others mapped the impact of building portfolio greenness and environmental quality on REITs financial performance [7,38].

Sah, Miller, and Ghosh [8] used Tobin's q as a proxy for green initiatives by REITs in 2009-2010. They found that green initiatives by managing REITs positively impacted firm value and higher return on assets. Schleich et al. [39] found that one of the drivers for REITs to specialize in green property is for global corporations to be willing to pay a premium for green buildings because of the lower expected running cost, long-term vacancy, and obsolescence risks. Lützkendorf and Lorenz [40] found that the inclusion of economic, environmental, and social factors in property valuation allows closer alignment with expected return from the property. Ref. [41] found that U.S. REITs holding environmentally sustainable buildings are favored by markets as they offer higher returns to investors. Similarly, Wilkinson et al. [42] found that U.K. property companies' return on investment (2001-2010) positively correlates to their higher CSR scores. In a study of U.S. equity REITs, Chiang, Wachtel, and Zhou [10] found that REITs with a greater CSR involvement had higher growth and investment opportunities. Benefield, Anderson, and Zumpano [13] studied the trading prices of REITs and found that the diversified REITs outperformed the specialized REITs when the markets were performing well. Other studies evaluated the impact of green buildings on REIT's financial performance focusing on specific real estate asset types such as office, retail or residential [38,43]. Hou and $\mathrm{Wu}[44]$ found that environmentally conscious tourists are more likely to pay a higher premium for hotels with better credentials of green building design, highlighting asset heterogeneity within each sector. Eichholtz et al. [43] demonstrated a positive impact of environmentally certified (e.g., energy star and LEED) real estate assets on the market performance of investments through a reduced spread of their bonds.

This relevant literature review highlights the variety of influences on a firm's CSR, depicted in our conceptual framework (Figure 1): the influence of the drivers of CSR (on the right), modified by the firm characteristics (central panel) resulting in the three pillars of CSR (left panel). This research concentrates on the impact of only two firm characteristics listed in the central panel. While prior research has highlighted that diversified assets result in increased REIT CSR [36], prior research has not teased out which type of real estate asset results in higher total REIT CSR output, nor which of its components (E, S, or G) is impacted, a lacuna this paper addresses. 
Left Panel

Drivers of CSR

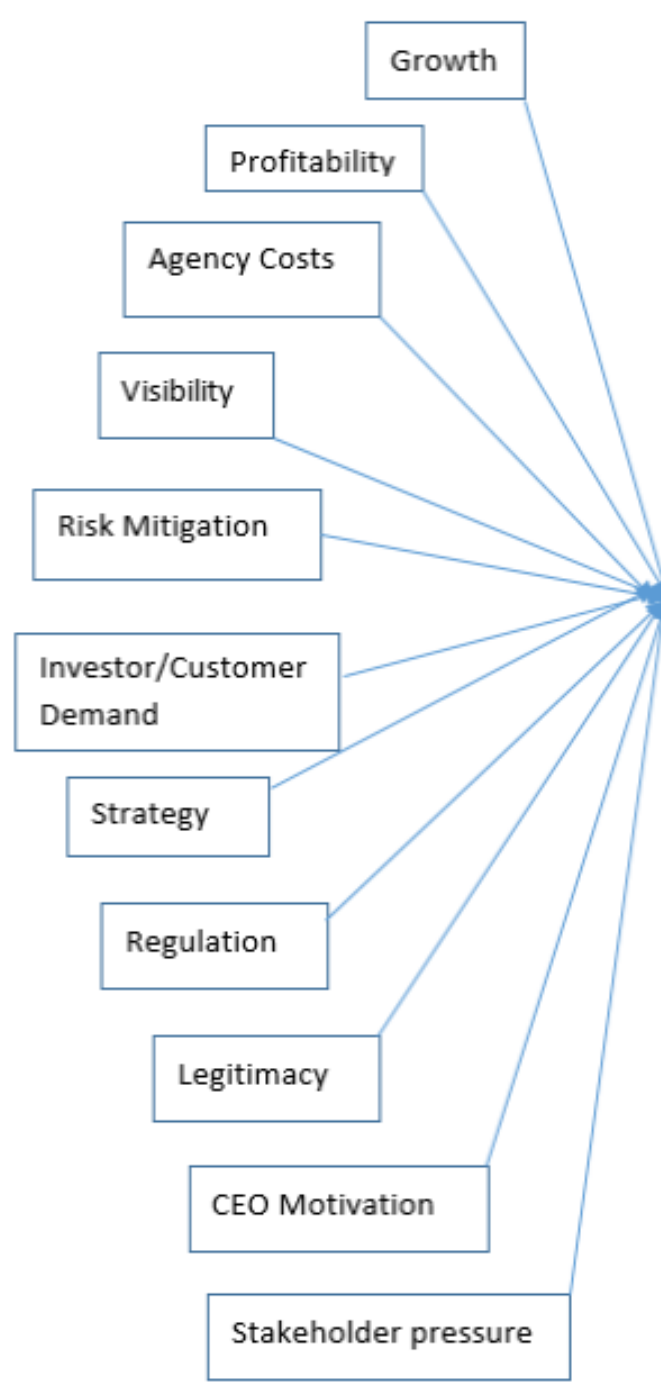

Centre Panel

Firm characteristics

Modifying CSR
Right Panel

3 Pillars of CSR

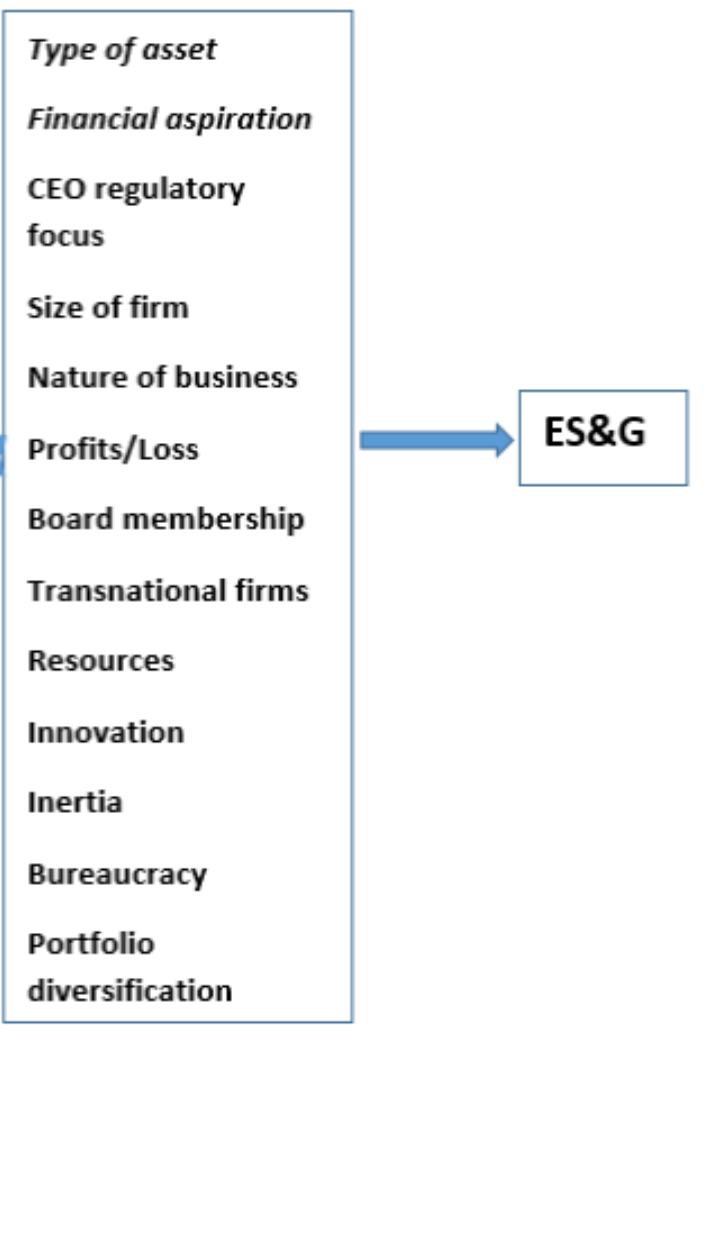

Figure 1. Conceptual framework: drivers of CSR and firm characteristics modifying the three pillars of CSR.

Given the complexity and variability in CSR and its measurement, leading CSR indices such as the MSCI report on company CSR in all three its pillars: ES\&G [45]. However, as far as the authors are aware, there is no prior literature on the ES\&G being mapped individually, at the same time at the sector level. Separate evaluations of the E, S, or G, however, are abundant in the literature. For instance, Kolk [46] investigated corporate governance in the Fortune 250 global companies; Dempsey et al. [47] mapped the social dimension of urban sustainability, and Orlitzky et al. [48] linked strategic CSR and environmental sustainability. We extend this approach in our empirical study focusing on the variability of real estate assets that REITs specialize in and its interaction with a firm's financial aspiration, which is lacking in the existing literature.

\section{Real Estate Asset Types, Financial Aspiration, and CSR: Hypothesis Development}

Considering the diversity of underlying forces that motivate REITs CSR, the existing literature falls short of insights on the heterogeneity of real estate assets and its impact on the ES\&G aspects of CSR among REITs. Differences in REITs' portfolio composition and investment strategies could contribute to or determine their CSR strategy and performance variations. 
The combination of capital and labor (often divided as land, building, and labor service) that forms a real estate asset dynamically corresponds to its production, i.e., land development and its operation, i.e., property management processes [49-51]. Therefore, it is sensible to postulate that REITs' underlying asset specificity will impose heterogeneous impacts on their ES\&G dimension CSR ratings. For example, hotel and hospital real estate assets are directly and significantly reliant on hospitality and health care services and facilities-hence, they are often associated with high energy and resource consumption and negative externality. In addition, they represent heavy users of polluting transport services for goods, clients, and staff and are much more costly to retrofit or replaced by more sustainable building stock [52]. In contrast, office, industrial, retail and residential properties often generate their service flow via physical building components, relying much less on labor-intensive human services. Rural property tends to rely its land productivity on the soil quality, climate, and state of agricultural technologies [53,54]. Understandably, REITs holding property assets of specific types are likely to have different types and degrees of social costs and may impose different governance and environmental costs, impacting asset market value and company image.

Atkeson [55] stated that a small proportion of the REITs portfolios are green certified, of which the office sector has the highest proportion of green-certified buildings across all real estate types. This variation in green certification of the real estate stock could link to the CSR performance of their asset-holding REIT. Thus, it is important to consider the basic features that define and differentiate real estate assets and their relevance to REITs ${ }^{\prime}$ portfolio strategy and CSR behaviors. We aim to fill this gap in knowledge about REITs' CSR performances across each of the three pillars ES\&G with variation in their portfolio type. Thus, we can state our first hypothesis as follows:

H1: All other things being equal, REITs by real estate asset portfolio types differ in their CSR performance across each of the ES\&G pillars.

The previous literature demonstrates a link between a firm's financial performance and its CSR performance (for example [56-58]). According to the behavioral theory of the firm, a firm's historical and social performances relative to its peers serve as aspirational reference points $[59,60]$, known as financial aspiration. This is relevant to the firm's strategy establishment [61]. Mount and Baer [31] found that a firm's higher CSR activity results from its performance above its expected financial aspiration level. Based on the literature discussed, we anticipate REITs focusing on specific real estate asset portfolio responses differently to their financial aspiration to contribute to each CSR dimension. The underlying proposition is that different real estate assets types are subject to specific external societal costs due to their physical, socio-economic, and environmental resource compositions. Specifically, our second hypothesis is as follows:

$\mathrm{H} 2$ : All else being equal, improvement of financial performance relative to aspiration motivates REITs to engage in more CSR directed at assets with the worst CSR.

\section{Empirical Model}

This research utilizes the MSCI Environmental Social and Governance Index (ESGI) to measure REITs' CSR performance worldwide. MSCI CSR ratings are constructed using a three-level framework where the raw data are assigned to the thirty-six key factors categorized under E, S \& G, normalized, weighted, and adjusted for the company- or industry-specific factors to derive the overall CSR scores. The raw data are sourced from company reports, private and academic researches, media, trade associations, industry watchdogs, and government statistics and are regularly verified (for methodology, please see [45]). The MCSI CSR ratings are scored between 0 and 10 and are widely used for research in real estate [62,63] and other industries [64-66]. Finally, this study chooses the MCSI rating rather than other CSR ratings like KLD STATS (Statistical Tool for Analysing Trends in Social and Environmental Performance) because the KLD STATS rating only covers U.S. companies, limiting research scope reduces testable sample size. 
To test hypothesis H1, we adopt multi-regression models to investigate the causal relationship between the real-estate portfolio composition and the CSR of REITs. In addition, we follow the recent literature to set the CSR performance of the REIT as dependent variables, real estate portfolio composition features as explanatory variables and include the financial information of the REITs as controlling variables to improve accuracy [67]. Finally, we develop the model Equation (1) below to investigate REITs CSR's variation by different focuses on real estate assets.

$$
\begin{aligned}
\text { CSR }_{\mathrm{i}, \mathrm{t}}=\alpha_{1}+ & \beta_{1} \times \text { Office }_{\mathrm{i}, \mathrm{t}}+\beta_{2} \times \text { Retail }_{\mathrm{i}, \mathrm{t}}+\beta_{3} \times \text { Residential }_{\mathrm{i}, \mathrm{t}} \\
& +\beta_{4} \times \text { Hotel }_{\mathrm{i}, \mathrm{t}}+\beta_{5} \times \text { Industry }_{\mathrm{i}, \mathrm{t}}+\beta_{6} \times \text { Hospital }_{\mathrm{i}, \mathrm{t}} \\
& +\beta_{7} \times \text { Others }_{\mathrm{i}, \mathrm{t}}+\mathrm{X}_{\mathrm{i}, \mathrm{t}}^{\prime}+\mu_{\mathrm{t}}+\delta_{\mathrm{c}}+\varepsilon_{\mathrm{i}, \mathrm{t}}
\end{aligned}
$$

where the dependent variable represents the specific CSR performance scores of the environment (Env-score), social (Soc-score) and governance (Gov-score) pillars, as well as the overall industry risk-adjusted CSR score (Overall-Score): $\mathrm{m}=(1$ to 4$)$. " $\mathrm{i}$ " and " $\mathrm{t}$ " indicate REIT " $\mathrm{i}$ " in the year " $\mathrm{t}$ " corresponding to a specific CSR pillar " $\mathrm{m}$." The independent dummy variables "Office," "Retail," "Residential," "Hotel," "Industry," "Hospital," and "Others" ( $n=1$ to 7 ) indicate the focus of REITs' real estate portfolio. For example, if a REIT specializes in office and retail property, the dummy variables "office" and "retail" are equal to " 1 ", and the rest of property type dummy variables are equal to " 0 ". "Others" is a dummy variable being " 1 " if the REIT contains more than three types (diversified) or specializes in other types such as rural land, mortgage, or prison, and it is used as a benchmark of causal effect compared to other property types in the empirical testing. The control variable " $X^{\prime \prime}$ " represents REITs' financial information using return on assets ("ROA"), a dummy variable on whether a REIT suffers a financial loss ("DLoss"), firm size ("Size") by logged total assets, and leverage ratio ("Leverage"), and the amount of acquisition scaled by the total asset ("Acquisition") to account for the other strategic actions undertaken by a REIT that may affect its CSR engagement at a specific point in time. The choice of these control variables is consistent with the previous literature [68-70]. We include country-fixed effect to control for the diversity of jurisdiction and countries $\left(\delta_{c}\right)$. We include year-fixed effect $\left(\mu_{t}\right)$ to control for the variation of CSR performance over time. Our empirical strategy adopts OLS and random effect models, clustering standard error at country or firm level, to estimate the model results for robustness.

The behavioral theory of the firm suggests a firm's financial performance relative to its financial aspiration level influences its strategic decisions, such as its CSR [61]. To reflect on how REITs establish their CSR strategies, we develop empirical models to test how the influence of the REIT's financial performance relative to its financial aspiration level on CSR vary by the types of real estate assets. We follow Audia and Greve [71], adopting return on assets (ROA) as a measure of financial performance to estimate each REIT's financial aspiration level in each year. The total level of aspiration (TA) is calculated by combining REITs' social and historical aspiration levels. The level of social aspiration (SA) is the average ROA of other peer REITs in each year's focal REITs country. The level of historical aspiration (HA) combines the focal REIT's prior-year historical aspiration level and financial performance. The HA and the TA are calculated using the equations:

$$
\begin{gathered}
\mathrm{HA}_{\mathrm{i}, \mathrm{t}}=\alpha_{1} \times \mathrm{HA}_{\mathrm{i}, \mathrm{t}-1}+\left(1-\alpha_{1}\right) \times \mathrm{ROA}_{\mathrm{i}, \mathrm{t}-1} \\
\mathrm{TA}_{\mathrm{i}, \mathrm{t}}=\alpha_{2} \times \mathrm{HA}_{\mathrm{i}, \mathrm{t}}+\left(1-\alpha_{2}\right) \times \mathrm{SA}_{\mathrm{i}, \mathrm{t}}
\end{gathered}
$$

The calculation of HA and TA in Equations (2) and (3) requires an estimation of their weights $\alpha_{1}$ and $\alpha_{2}$. We follow Greve [72] and Rudy and Johnson [61] to estimate the values of $\alpha_{1}$ and $\alpha_{2}$ of HA and TA, as additional independent variables in model Equation (1), which achieve the best fit in the model according to the Wald test, by substituting all values between 0 and 1 in 0.1 increments. The values of $\alpha_{1}$ and $\alpha_{2}$ that give the best fit to model Equation (1) will determine HA and TA. The values of $\alpha_{1}$ correspond to with the dependent variables for Equation (1) being the overall, E, S and G CSR scores are 0, 
$0.1,0$ and 0.9 . The values of $\alpha_{2}$ are $0.15,0,0.6$ and 0.75 for Equation (1) regarding the dependent variables being the overall, E, S, and G CSR scores. The findings indicate that REITs differ by factoring in their financial performance aspiration to establish their CSR pillars strategy. Further, we generate the variable "D_TA" to measure REITs' financial performance relative to their TA for each CSR pillar. "D_TA" is equal to the focal REIT's ROA minus its TA. To test hypothesis H2, we further develop the empirical model, Equation (4) that captures REITs' financial performance relative to their financial aspiration level. It introduces a moderating effect to the real estate asset-specific CSR performance variations that Equation (1) introduces.

$$
\begin{aligned}
\text { CSR }_{\mathrm{i}, \mathrm{t}}=\alpha_{1}+ & \beta_{1} \times \text { Office }_{i, \mathrm{t}}+\beta_{2} \times \text { Retail }_{\mathrm{i}, \mathrm{t}}+\beta_{3} \times \text { Residential }_{\mathrm{i}, \mathrm{t}} \\
& +\beta_{4} \times \text { Hotel }_{\mathrm{i}, \mathrm{t}}+\beta_{5} \times \text { Industry }_{\mathrm{i}, \mathrm{t}}+\beta_{6} \times \text { Hospital }_{\mathrm{i}, \mathrm{t}} \\
& +\beta_{7} \times \text { Others }_{\mathrm{i}, \mathrm{t}}+\beta_{8} \times \text { Office }_{\mathrm{i}, \mathrm{t}} \times \mathrm{D}_{-} \mathrm{TA}_{\mathrm{i}, \mathrm{t}-1} \\
& +\beta_{9} \times \text { Retail }_{\mathrm{i}, \mathrm{t}} \times \mathrm{D}_{-} \mathrm{TA}_{\mathrm{i}, \mathrm{t}-1} \\
& +\beta_{10} \times \text { Residential }_{\mathrm{i}, \mathrm{t}} \times \mathrm{D}_{-} \mathrm{TA}_{\mathrm{i}, \mathrm{t}-1} \\
& +\beta_{11} \times \text { Hotel }_{\mathrm{i}, \mathrm{t}} \times \mathrm{D}_{-} \mathrm{TA}_{\mathrm{i}, \mathrm{t}-1} \\
& +\beta_{12} \times \text { Industry }_{\mathrm{i}, \mathrm{t}} \times \mathrm{D}_{-} \mathrm{TA} \mathrm{A}_{\mathrm{i}, \mathrm{t}-1} \\
& +\beta_{13} \times \text { Hospital }_{\mathrm{i}, \mathrm{t}} \times \mathrm{D}_{-} \mathrm{TA}_{\mathrm{i}, \mathrm{t}-1} \\
& +\beta_{14} \times \text { Others }_{\mathrm{i}, \mathrm{t}} \times \mathrm{D}_{-} \mathrm{TA}_{\mathrm{i}, \mathrm{t}-1}+\mathrm{X}_{\mathrm{i}, \mathrm{t}}^{\prime}+\mu_{\mathrm{t}}+\delta_{\text {Country }} \\
& +\varepsilon_{\mathrm{i}, \mathrm{t}}
\end{aligned}
$$

where the dependent variable represents the CSR, performance scores of governance (Govscore), social (Soc-score), environment (Env-score) pillars, and the industry risk-adjusted overall CSR score (Overall-Score). We generate one "D_TA," which indicates the focal REITs' financial performance relative to the aspiration level with one year lag for each CSR measure. The rest of the model specification is the same as Equation (1), except it only clusters the standard error at the firm level.

\section{Data and Sample Description}

A panel dataset is compiled using financial data obtained from the Wharton Research Data Services (WRDS) and MSCI CSR rating indexes. This includes all the countries and all the REITs listed by MSCI. In addition, real estate portfolio data were manually collected from REITs' financial reports. Table 1 shows the statistical summary of the dataset, including the country dummy variables.

Table 1 shows that the average corporate governance score is 6.5 , which is significantly higher than the scores of the other CSR pillars and the overall score. One likely contributor to this discrepancy is REIT's rigid compliance with a strict regulatory regime to maintain its operation as a pass-through entity to avoid income tax at the corporation level. Compared to other companies, ceteris paribus, REITs have a less complex corporate structure and more transparent corporate governance. REITs' structural rigidity contributes to its higher CSR governance score, and it helps reduce bias in empirical testing caused by firm heterogeneity. The dataset shows that office is the most popular real estate asset type in REITs investment portfolios. In total, 33\% of the REITs invest in office as the main real estate asset in their portfolio, followed by retail (30.3\%) and industrial including warehouse $(20.9 \%)$. The residential, hotel, and hospital assets percentages are $16.8 \%, 7 \%$, and $5.4 \%$. As the table shows, the percentages of the real estate type indicating variables add up more than $100 \%$ because some REITs specialize in two real estate asset types, which have two dummy variables of real estate type that are equal to " 1 ". The mean VIF of independent variables is 1.29 and the VIF statistics of all independent variables are below 1.63 (Table 2). Thus, multicollinearity does not bother the empirical estimation. 
Table 1. Statistical summary of the database.

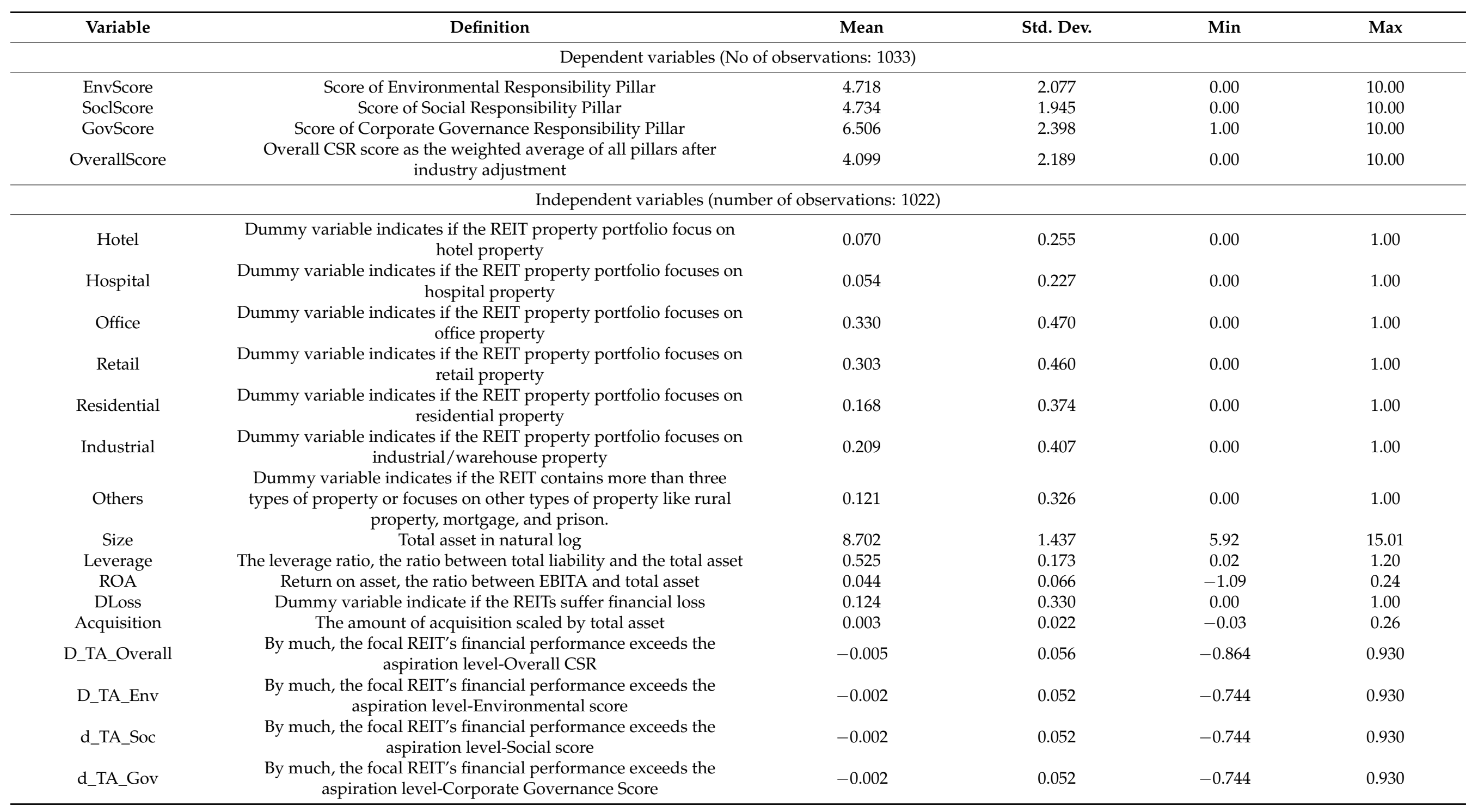


Table 1. Cont.

\begin{tabular}{|c|c|c|c|c|c|}
\hline Variable & Definition & Mean & Std. Dev. & Min & Max \\
\hline $\mathrm{AU}$ & Dummy variable indicating if the REIT is listed in Australia & 0.135 & 0.342 & 0.00 & 1.00 \\
\hline $\mathrm{BE}$ & Dummy variable indicating if the REIT is listed in Belgium & 0.004 & 0.062 & 0.00 & 1.00 \\
\hline CA & Dummy variable indicating if the REIT is listed in Canada & 0.052 & 0.222 & 0.00 & 1.00 \\
\hline DE & Dummy variable indicating if the REIT is listed in Germany & 0.002 & 0.044 & 0.00 & 1.00 \\
\hline FR & Dummy variable indicating if the REIT is listed in France & 0.041 & 0.199 & 0.00 & 1.00 \\
\hline GB & Dummy variable indicating if the REIT is listed in UK & 0.022 & 0.145 & 0.00 & 1.00 \\
\hline GR & Dummy variable indicating if the REIT is listed in Greece & 0.001 & 0.031 & 0.00 & 1.00 \\
\hline HK & Dummy variable indicating if the REIT is listed in Hong Kong & 0.013 & 0.112 & 0.00 & 1.00 \\
\hline IT & Dummy variable indicating if the REIT is listed in Italy & 0.004 & 0.062 & 0.00 & 1.00 \\
\hline $\mathrm{JP}$ & Dummy variable indicating if the REIT is listed in Japan & 0.038 & 0.192 & 0.00 & 1.00 \\
\hline $\mathrm{MX}$ & Dummy variable indicating if the REIT is listed in Mexico & 0.003 & 0.054 & 0.000 & 1.000 \\
\hline MY & Dummy variable indicating if the REIT is listed in Malaysia & 0.002 & 0.044 & 0.000 & 1.000 \\
\hline NL & Dummy variable indicating if the REIT is listed in the Netherland & 0.019 & 0.135 & 0.000 & 1.000 \\
\hline NZ & Dummy variable indicating if the REIT is listed in New Zealand & 0.001 & 0.031 & 0.000 & 1.000 \\
\hline SG & Dummy variable indicating if the REIT is listed in Singapore & 0.017 & 0.128 & 0.000 & 1.000 \\
\hline TR & Dummy variable indicating if the REIT is listed in Turkey & 0.003 & 0.054 & 0.000 & 1.000 \\
\hline US & Dummy variable indicating if the REIT is listed in the U.S & 0.630 & 0.483 & 0.000 & 1.000 \\
\hline
\end{tabular}


Table 2. Correlation coefficients.

\begin{tabular}{|c|c|c|c|c|c|c|c|c|c|c|c|c|c|c|c|c|c|c|c|c|c|}
\hline & & (1) & (2) & (3) & (4) & (5) & (6) & (7) & (8) & (9) & (10) & (11) & (12) & (13) & (14) & (15) & (16) & (17) & (18) & (19) & VIF \\
\hline EnvScore & (1) & 1.00 & & & & & & & & & & & & & & & & & & & \\
\hline SoclScore & (2) & 0.13 & 1.00 & & & & & & & & & & & & & & & & & & \\
\hline GovScore & (3) & -0.02 & 0.10 & 1.00 & & & & & & & & & & & & & & & & & \\
\hline Hotel & (5) & -0.10 & -0.15 & -0.03 & -0.16 & 1.00 & & & & & & & & & & & & & & & 1.15 \\
\hline Hospital & (6) & -0.11 & -0.08 & -0.07 & -0.15 & -0.07 & 1.00 & & & & & & & & & & & & & & 1.27 \\
\hline Office & (7) & 0.26 & -0.02 & -0.03 & 0.18 & -0.11 & -0.17 & 1.00 & & & & & & & & & & & & & 1.41 \\
\hline Retail & (8) & -0.02 & 0.02 & -0.05 & -0.03 & -0.06 & -0.16 & -0.09 & 1.00 & & & & & & & & & & & & 1.41 \\
\hline Industrial & (10) & 0.10 & 0.06 & 0.09 & 0.12 & -0.14 & -0.12 & 0.08 & -0.11 & -0.09 & 1.00 & & & & & & & & & & 1.27 \\
\hline Others & (11) & -0.16 & 0.09 & 0.05 & 0.02 & -0.10 & -0.09 & -0.26 & -0.24 & -0.17 & -0.19 & 1.00 & & & & & & & & & 1.62 \\
\hline Size & (12) & 0.07 & 0.02 & -0.09 & 0.08 & -0.01 & -0.11 & 0.23 & 0.10 & 0.03 & -0.05 & 0.01 & 1.00 & & & & & & & & 1.12 \\
\hline Leverage & (13) & -0.21 & -0.01 & -0.04 & -0.19 & 0.00 & 0.02 & -0.25 & -0.02 & 0.03 & -0.20 & 0.31 & 0.04 & 1.00 & & & & & & & 1.26 \\
\hline ROA & (14) & 0.04 & 0.01 & 0.05 & 0.04 & -0.01 & 0.03 & 0.02 & 0.07 & -0.05 & 0.08 & -0.06 & 0.04 & -0.19 & 1.00 & & & & & & 1.22 \\
\hline DLoss & (15) & -0.09 & 0.04 & 0.00 & -0.02 & 0.00 & -0.06 & -0.01 & -0.05 & 0.05 & -0.04 & 0.08 & -0.08 & 0.21 & -0.39 & 1.00 & & & & & 1.24 \\
\hline Acquisition & (16) & 0.05 & 0.02 & 0.00 & 0.02 & -0.02 & -0.02 & -0.08 & -0.06 & -0.02 & 0.13 & 0.03 & 0.05 & 0.10 & 0.01 & 0.02 & 1.00 & & & & 1.05 \\
\hline D_TA1_Overall & (17) & 0.04 & 0.01 & -0.01 & 0.05 & -0.03 & -0.03 & 0.03 & -0.03 & -0.02 & 0.04 & 0.08 & -0.02 & -0.07 & 0.02 & 0.05 & -0.02 & 1.00 & & & 1.03 \\
\hline D_TA1_Env & (18) & 0.05 & 0.02 & -0.02 & 0.06 & -0.03 & -0.03 & 0.03 & -0.02 & -0.01 & 0.02 & 0.06 & -0.03 & -0.08 & 0.01 & 0.07 & -0.02 & 0.84 & 1.00 & & 1.03 \\
\hline & & & & & & & & & & & & & & & & & & \multicolumn{3}{|c|}{ Mean VIF } & 1.29 \\
\hline
\end{tabular}

Note: This table exhibits the correlation coefficients of all the variables used in the empirical test and the VIF test results of the independent variables in models Equations (1) and (4). 


\section{Results and Findings}

\subsection{Differences in REIT CSR Performance by Asset Types}

Table 3 presents the results of Equation (1) testing hypothesis H1. It shows that the REITs with larger total asset size, lower leverage ratio (financial risk), and better financial performance were better across all the CSR performance categories. The REITs engaged in more acquisition activity performed better in the environment CSR rating and performed the worst in social and governance pillars.

Table 3. REITs' CSR performance and property portfolio composition.

\begin{tabular}{|c|c|c|c|c|c|c|c|c|}
\hline \multirow[t]{2}{*}{ Variables } & \multicolumn{2}{|c|}{ Environment Score } & \multicolumn{2}{|c|}{ Social Score } & \multicolumn{2}{|c|}{ Governance Score } & \multicolumn{2}{|c|}{ Overall CSR Score } \\
\hline & (1) & (2) & (3) & (4) & (5) & (6) & (7) & (8) \\
\hline Hotel & $\begin{array}{l}-0.530^{* *} \\
(-2.214)\end{array}$ & $\begin{array}{l}-0.714^{* *} \\
(-2.402)\end{array}$ & $\begin{array}{c}-0.789 * * * \\
(-4.074)\end{array}$ & $\begin{array}{c}-0.721^{* * *} \\
(-4.916)\end{array}$ & $\begin{array}{c}-0.0294 \\
(-0.0708)\end{array}$ & $\begin{array}{c}-0.124 \\
(-0.527)\end{array}$ & $\begin{array}{c}-0.870 * * * \\
(-3.207)\end{array}$ & $\begin{array}{c}-0.878^{* * *} \\
(-4.784)\end{array}$ \\
\hline Hospital & $\begin{array}{c}-0.731^{* * *} \\
(-3.490)\end{array}$ & $\begin{array}{c}-0.675^{* * *} \\
(-3.191)\end{array}$ & $\begin{array}{l}-0.114 \\
(-0.441)\end{array}$ & $\begin{array}{l}-0.0497 \\
(-0.369)\end{array}$ & $\begin{array}{l}-0.715 \\
(-1.287)\end{array}$ & $\begin{array}{c}-0.745 \\
(-1.502)\end{array}$ & $\begin{array}{l}-0.868 \text { ** } \\
(-2.375)\end{array}$ & $\begin{array}{c}-0.862^{* * *} \\
(-4.209)\end{array}$ \\
\hline Office & $\begin{array}{c}0.642^{* * *} \\
(3.313)\end{array}$ & $\begin{array}{c}0.549^{* * *} \\
(2.835)\end{array}$ & $\begin{array}{c}-0.151 \\
(-0.862)\end{array}$ & $\begin{array}{c}-0.104 \\
(-0.998)\end{array}$ & $\begin{array}{l}-0.306 \\
(-1.301)\end{array}$ & $\begin{array}{c}-0.338 \\
(-1.193)\end{array}$ & $\begin{array}{c}0.393 \\
(1.185)\end{array}$ & $\begin{array}{c}0.318 \\
(1.115)\end{array}$ \\
\hline Retail & $\begin{array}{c}-0.403 \\
(-1.227)\end{array}$ & $\begin{array}{l}-0.560^{* *} \\
(-2.036)\end{array}$ & $\begin{array}{c}0.172 \\
(0.994)\end{array}$ & $\begin{array}{c}0.139 \\
(1.460)\end{array}$ & $\begin{array}{c}-0.140 \\
(-0.595)\end{array}$ & $\begin{array}{l}-0.110 \\
(-1.067)\end{array}$ & $\begin{array}{c}-0.305 \\
(-0.942)\end{array}$ & $\begin{array}{l}-0.402 * \\
(-1.829)\end{array}$ \\
\hline Residential & $\begin{array}{c}-0.0142 \\
(-0.0316)\end{array}$ & $\begin{array}{c}-0.108 \\
(-0.246)\end{array}$ & $\begin{array}{l}0.429 * * \\
(2.177)\end{array}$ & $\begin{array}{l}0.443^{* *} \\
(2.554)\end{array}$ & $\begin{array}{c}0.119 \\
(0.429)\end{array}$ & $\begin{array}{c}0.160 \\
(1.030)\end{array}$ & $\begin{array}{c}0.178 \\
(0.490)\end{array}$ & $\begin{array}{c}0.113 \\
(0.249)\end{array}$ \\
\hline Industry & $\begin{array}{c}-0.153 \\
(-0.884)\end{array}$ & $\begin{array}{l}0.0216 \\
(0.108)\end{array}$ & $\begin{array}{c}0.349 \\
(1.573)\end{array}$ & $\begin{array}{c}0.417^{* *} \\
(1.960)\end{array}$ & $\begin{array}{c}0.228 \\
(1.014)\end{array}$ & $\begin{array}{c}0.164 \\
(0.715)\end{array}$ & $\begin{array}{l}0.0870 \\
(0.209)\end{array}$ & $\begin{array}{c}0.195 \\
(0.753)\end{array}$ \\
\hline Others & $\begin{array}{c}-0.878 \\
(-1.667)\end{array}$ & $\begin{array}{l}-0.998^{*} \\
(-1.685)\end{array}$ & $\begin{array}{c}0.297 \\
(1.093)\end{array}$ & $\begin{array}{c}0.350 * * * \\
(4.030)\end{array}$ & $\begin{array}{l}0.0500 \\
(0.136)\end{array}$ & $\begin{array}{c}0.118 \\
(0.552)\end{array}$ & $\begin{array}{c}0.187 \\
(0.431)\end{array}$ & $\begin{array}{c}0.215 \\
(0.609)\end{array}$ \\
\hline Size & $\begin{array}{c}0.460^{* * *} \\
(10.79)\end{array}$ & $\begin{array}{c}0.389 * * * \\
(8.194)\end{array}$ & $\begin{array}{c}0.240 * * * \\
(2.867)\end{array}$ & $\begin{array}{c}0.224 * * * \\
(3.530)\end{array}$ & $\begin{array}{c}0.185 \\
(1.644)\end{array}$ & $\begin{array}{c}0.222^{* * *} \\
(5.137)\end{array}$ & $\begin{array}{c}0.634^{* * *} \\
(4.795)\end{array}$ & $\begin{array}{c}0.578^{* * *} \\
(7.663)\end{array}$ \\
\hline Leverage & $\begin{array}{c}-1.133 \\
(-1.468)\end{array}$ & $\begin{array}{c}-0.883 \\
(-1.169)\end{array}$ & $\begin{array}{l}-0.957 \text { * } \\
(-1.894)\end{array}$ & $\begin{array}{l}-0.858^{*} \\
(-1.722)\end{array}$ & $\begin{array}{c}-1.055 \\
(-1.486)\end{array}$ & $\begin{array}{c}-1.364^{* * *} \\
(-3.794)\end{array}$ & $\begin{array}{l}-1.669^{* *} \\
(-2.371)\end{array}$ & $\begin{array}{l}-1.777^{*} \\
(-1.893)\end{array}$ \\
\hline ROA & $\begin{array}{c}0.588 \\
(0.586)\end{array}$ & $\begin{array}{c}0.256 \\
(0.333)\end{array}$ & $\begin{array}{c}1.381 \\
(1.639)\end{array}$ & $\begin{array}{l}1.260^{* *} \\
(2.319)\end{array}$ & $\begin{array}{c}0.0876 \\
(0.0936)\end{array}$ & $\begin{array}{c}0.0497 \\
(0.0371)\end{array}$ & $\begin{array}{c}1.520 \\
(1.429)\end{array}$ & $\begin{array}{c}0.884 \\
(1.020)\end{array}$ \\
\hline DLoss & $\begin{array}{c}-0.536^{* * *} \\
(-7.708)\end{array}$ & $\begin{array}{c}-0.401^{* * *} \\
(-5.279)\end{array}$ & $\begin{array}{c}0.246 \\
(1.590)\end{array}$ & $\begin{array}{c}0.313^{* * *} \\
(5.363)\end{array}$ & $\begin{array}{c}-0.0205 \\
(-0.0873)\end{array}$ & $\begin{array}{l}-0.0765 \\
(-0.639)\end{array}$ & $\begin{array}{c}-0.188 \\
(-0.714)\end{array}$ & $\begin{array}{l}-0.129^{* *} \\
(-2.050)\end{array}$ \\
\hline Acquisition & $\begin{array}{c}6.802 * * * \\
(5.423)\end{array}$ & $\begin{array}{c}1.609 * * * \\
(2.878)\end{array}$ & $\begin{array}{c}-0.924 \\
(-0.453)\end{array}$ & $\begin{array}{c}-1.374^{* * *} \\
(-4.902)\end{array}$ & $\begin{array}{l}-4.726 \\
(-1.360)\end{array}$ & $\begin{array}{c}-3.983 * * * \\
(-4.320)\end{array}$ & $\begin{array}{c}2.168 \\
(0.796)\end{array}$ & $\begin{array}{l}-0.00133 \\
(-0.00417)\end{array}$ \\
\hline Constant & $\begin{array}{c}2.373^{* * *} \\
(8.003)\end{array}$ & $\begin{array}{c}2.713 * * * \\
(5.703)\end{array}$ & $\begin{array}{c}3.667^{* * * *} \\
(5.508)\end{array}$ & $\begin{array}{c}3.652 * * * \\
(11.68)\end{array}$ & $\begin{array}{c}5.560 * * * \\
(5.876)\end{array}$ & $\begin{array}{c}5.404^{* * *} \\
(18.99)\end{array}$ & $\begin{array}{c}0.230 \\
(0.203)\end{array}$ & $\begin{array}{c}0.411 \\
(0.546)\end{array}$ \\
\hline Observations & 1017 & 1017 & 1017 & 1017 & 1017 & 1017 & 1017 & 1017 \\
\hline $\begin{array}{l}\text { Number of } \\
\text { REITs }\end{array}$ & & 485 & & 485 & & 485 & & 485 \\
\hline $\begin{array}{l}\text { R-squared } \\
\text { Prob > chi2 }\end{array}$ & 0.280 & $\begin{array}{l}0.263 \\
0.000\end{array}$ & 0.517 & $\begin{array}{l}0.515 \\
0.000\end{array}$ & 0.230 & $\begin{array}{l}0.229 \\
0.000\end{array}$ & 0.358 & $\begin{array}{l}0.344 \\
0.000\end{array}$ \\
\hline Year FE & YES & $\begin{array}{l}0.000 \\
\text { YES }\end{array}$ & YES & $\begin{array}{l}0.000 \\
\text { YES }\end{array}$ & YES & $\begin{array}{l}0.000 \\
\text { YES }\end{array}$ & YES & $\begin{array}{l}0.000 \\
\text { YES }\end{array}$ \\
\hline Country FE & YES & YES & YES & YES & YES & YES & YES & YES \\
\hline $\begin{array}{c}\text { SE } \\
\text { Clustering }\end{array}$ & Firm & Country & Firm & Country & Firm & Country & Firm & Country \\
\hline $\begin{array}{l}\text { Random } \\
\text { Effect }\end{array}$ & & YES & & YES & & YES & & YES \\
\hline
\end{tabular}

Note: This table reports the model Equation (1) investigating how the property portfolio composition influence the REITs' CSR performance in each pillar and overall. Year and country fixed effect are included in each Column. Columns (1), (3), (5) and (7) cluster the standard error by the firm. Columns (2), (4), (6) and (8) adopt the random effect model and cluster the standard error by country. T-statistics in parentheses; ${ }^{* * *} p<0.01 ;{ }^{* *} p<0.05 ;{ }^{*} p<0.1$.

For the key real estate portfolio type variables, we find that the REITs focussing on hotel and hospital assets are $5.3 \%$ to $7.14 \%$, and $6.75 \%$ to $7.31 \%$ lower in environment scores than other REITs. On the other hand, REITs that specialize in office assets exhibit higher environment scores $(5.49-6.42 \%)$ than the rest. In addition, the REITs specializing in hotel real estate assets receive lower social SCR ratings than the other REITs by $7.21 \%$ to $7.89 \%$. 
In comparison, REITs focusing on residential assets achieve higher social SCR scores than others by $4.29 \%$ to $4.43 \%$. The corresponding coefficients are statistically significant, at least at a $5 \%$ confidence level.

Columns (5) and (6) of Table 3 show that REITs' governance CSR rating does not differentiate by the variation of real estate types on a statistically significant level. Columns (7) and (8) present test results of the overall CSR ratings by a weighted adjusted average of CSR scores as the dependent variable. Compared to other REITs, the REITs specializing in hotel and hospital assets have statistically significant lower CSR scores by $8.7 \%$ and $8.6 \%$, respectively.

The findings indicate that diverse relations exist between REITs' CSR ratings and the real estate asset type they hold and specialize in. The strategy of REITs real estate asset types and their CSR performance breakdowns reveal the empirical patterns matching specific real estate asset types held by REITs and their specific CSR concerns. In the discussion section, we explain these asset-specific correlations with the REITs CSR performances.

\subsection{Moderation of CSR by Financial Aspiration}

Table 4 presents the test results of Equation (4) testing hypothesis H2, which investigates how REITs' financial aspiration moderates their CSR ratings concerning the type(s) of real estate asset they specialize in. Columns (1) to (4) of Table 4 present the results of the overall and the ES\&G CSR rating scores. The resulting coefficients of the property-type variables and the control variables are showing signs consistent with the literature. Columns (1) and (2) show the coefficients of "D_TA," indicating the amount that the REITs financial performance relative to the financial aspiration level is positive and statistically significant with the overall and the environment CSR scores as the dependent variable. These findings show that when REITs' financial performance improves relatively to the aspiration level, they invest more in their CSR, especially in their environmental responsibility, leading to a better CSR performance.

Importantly, the test results show that the REITs focused on different real estate asset types are moderated by the financial aspiration differently when establishing their CSR strategy as interaction variables "XXX*d_TA" show to attest Hypothesis H2. For example, as the coefficients of the interaction variable "Hotel*D_TA" show, the improvement in financial performance motivates Hotel-REITs to invest more in CSR, especially their environment pillar score. However, the coefficients of "Office* D_TA" and "Retail ${ }^{*}$ D_TA" show that CSR performances of Office-REITs and Retail-REITs decline after their financial performance relative to the aspiration improved. These findings indicate that rea- estate asset portfolio differences led to different prioritization of CSR goals and financial goals in establishing CSR strategy by REITs. 
Table 4. REITs' CSR performance moderated by financial performance aspiration.

\begin{tabular}{|c|c|c|c|c|}
\hline & (1) & (2) & (3) & (4) \\
\hline Variables & Overall CSR & Environment & Social & Governance \\
\hline \multirow[t]{2}{*}{ Hotel } & $-0.887^{* * *}$ & $-0.513^{* *}$ & $-0.981^{* * *}$ & 0.531 \\
\hline & $(-3.128)$ & $(-1.998)$ & $(-3.863)$ & $(1.356)$ \\
\hline \multirow[t]{2}{*}{ Hospital } & $-0.815^{*}$ & $-0.894^{* *}$ & -0.0651 & -0.480 \\
\hline & $(-1.877)$ & $(-2.016)$ & $(-0.155)$ & $(-0.703)$ \\
\hline \multirow[t]{2}{*}{ Office } & $0.643 *$ & $0.804^{* * *}$ & -0.324 & -0.0544 \\
\hline & (1.677) & $(2.628)$ & $(-1.474)$ & $(-0.214)$ \\
\hline \multirow[t]{2}{*}{ Retail } & -0.398 & -0.337 & 0.196 & -0.365 \\
\hline & $(-1.218)$ & $(-1.187)$ & $(1.045)$ & $(-1.523)$ \\
\hline \multirow[t]{2}{*}{ Residential } & 0.198 & -0.127 & $0.450 * *$ & 0.0187 \\
\hline & $(0.509)$ & $(-0.406)$ & $(2.028)$ & $(0.0607)$ \\
\hline \multirow[t]{2}{*}{ Industry } & -0.0262 & -0.279 & 0.369 & 0.342 \\
\hline & $(-0.0568)$ & $(-0.817)$ & $(1.453)$ & $(1.468)$ \\
\hline \multirow[t]{2}{*}{ Others } & 0.0142 & $-0.937^{* *}$ & 0.108 & 0.0988 \\
\hline & $(0.0283)$ & $(-2.058)$ & $(0.299)$ & $(0.231)$ \\
\hline \multirow[t]{2}{*}{ d_TA } & $14.44^{* *}$ & $9.604 * * *$ & 4.349 & 3.138 \\
\hline & $(2.577)$ & $(2.646)$ & $(1.358)$ & $(1.065)$ \\
\hline \multirow[t]{2}{*}{ Hotel$^{*} \mathrm{~d}_{-} \mathrm{TA}$} & $46.42 * * *$ & $38.08 * *$ & -5.139 & -4.43 \\
\hline & $(3.066)$ & $(2.226)$ & $(-0.308)$ & $(-0.272)$ \\
\hline \multirow[t]{2}{*}{ Hospital*d_TA } & 9.037 & -22.10 & 17.96 & -0.621 \\
\hline & $(0.597)$ & $(-0.866)$ & $(0.631)$ & $(-0.0268)$ \\
\hline \multirow[t]{2}{*}{ Office $^{*}$ d_TA } & $-9.362 *$ & $-9.561^{* * *}$ & $-5.075^{*}$ & -3.812 \\
\hline & $(-1.676)$ & $(-2.764)$ & $(-1.722)$ & $(-1.439)$ \\
\hline \multirow[t]{2}{*}{ Retail $^{*}$ d_TA } & $-14.56^{* * *}$ & $-6.074^{*}$ & -1.185 & -1.337 \\
\hline & $(-2.713)$ & $(-1.661)$ & $(-0.446)$ & $(-0.515)$ \\
\hline \multirow[t]{2}{*}{ Residential $^{*}$ d_TA } & 3.406 & -1.741 & 1.027 & -0.241 \\
\hline & $(0.979)$ & $(-0.470)$ & $(0.396)$ & $(-0.0800)$ \\
\hline \multirow[t]{2}{*}{ Industry* d_TA } & -7.971 & -6.718 & -0.911 & -1.513 \\
\hline & $(-1.595)$ & $(-1.563)$ & $(-0.235)$ & $(-0.474)$ \\
\hline \multirow[t]{2}{*}{ Others*d_TA } & $-34.31 *$ & -20.86 & -2.309 & 3.692 \\
\hline & $(-1.865)$ & $(-1.122)$ & $(-0.203)$ & $(0.383)$ \\
\hline \multirow[t]{2}{*}{ size } & $0.684^{* * *}$ & $0.543^{* * *}$ & $0.273^{* * *}$ & -0.0157 \\
\hline & (4.799) & (4.391) & $(2.641)$ & $(-0.118)$ \\
\hline \multirow[t]{2}{*}{ Leverage } & -1.109 & -0.563 & $-1.022 *$ & -0.308 \\
\hline & $(-1.162)$ & $(-0.752)$ & $(-1.653)$ & $(-0.339)$ \\
\hline \multirow[t]{2}{*}{ Dloss } & $-0.616^{*}$ & $-0.844^{* * *}$ & 0.129 & -0.277 \\
\hline & $(-1.867)$ & $(-2.787)$ & $(0.658)$ & $(-0.851)$ \\
\hline \multirow[t]{2}{*}{ Acquisition } & 6.347 & $11.23^{* *}$ & 0.772 & -0.956 \\
\hline & $(1.462)$ & $(2.227)$ & $(0.202)$ & $(-0.124)$ \\
\hline \multirow[t]{2}{*}{ Constant } & -0.485 & 1.178 & $3.546^{* * *}$ & $7.012 * * *$ \\
\hline & $(-0.373)$ & $(1.070)$ & $(4.284)$ & $(5.957)$ \\
\hline Observations & 1016 & 1016 & 1016 & 1016 \\
\hline R-squared & 0.455 & 0.349 & 0.515 & 0.292 \\
\hline Year FE & YES & YES & YES & YES \\
\hline Country FE & YES & YES & YES & YES \\
\hline Firm Cluster & YES & YES & YES & YES \\
\hline
\end{tabular}

Note: This table reports the model Equation (4) to investigate how the influence of property portfolio composition on the CSR performance of REITs is moderated by financial performance aspiration. The dependent variables used in model Equation (4) are overall CSR score, environmental pillar score, social pillar score, and corporate governance pillar score in Column (1) to (4). Random effect estimator is used, and we include year and country fixed effect and cluster the standard error by country. T-statistics in parentheses; ${ }^{* * *} p<0.01$; ${ }^{* *} p<0.05$; $* p<0.1$

\section{Discussion and Conclusions}

This research provides a nuanced analysis of the role of different real estate asset types in REITs asset holding strategy and their CSR performance across the three pillars ES\&G for the first time (Figure 1). Our study contributes to filling this gap in the literature by demonstrating that empirically "asset type" (type of real estate holding) impacts REITs CSR 
ratings. Furthermore, REITs specialization in different real estate assets can have varying degrees of impact on their CSR ratings in each of the three ES\&G dimensions. Table 5 establishes a 'CSR-Asset matrix' summarising the empirical findings of the variation of the ES\&G pillars and their overall CSR scores by the differences in their real estate portfolio specialization.

Table 5. Summary of findings-CSR and Property Portfolio.

\begin{tabular}{ccccc}
\hline & Environment & Social & Governance & Overall CSR \\
\hline Hotel & - & - & $/$ & - \\
Hospital & - & $/$ & $/$ & - \\
Office & + & $/$ & $/$ & $/$ \\
Retail & $/$ & $/$ & $/$ & $/$ \\
Residential & $/$ & + & $/$ & $/$ \\
Industry & $/$ & $/$ & $/$ & \\
\hline
\end{tabular}

Note: This table summarizes the findings of the empirical tests regarding the variation of each pillar CSR and overall CSR scores by differences in the REIT property portfolio composition. "-" means negative correlation, and "+" means positive correlation. "/" indicate no statistically significant correlation is found. We set at least $5 \%$ statistically significant confidence coefficients in at least three model settings (columns) in each table as the requirement of confirming the correlation.

Hotels and hospitals are typical examples of less market-transparent real-estate assets due to intensive human-based services, business confidentiality, and physical capital input than technology-driven buildings. These service-intensive real estate asset types are usually capital resource-intensive, which raises their environmental and social externalities. In addition, governments heavily regulate healthcare properties such as hospitals; therefore, although capital and labor-intensive, hospital asset social CSR ratings perform indifferently to the rest of REITs asset types.

Of the environment and social CSR dimensions, commercial offices and part of residential and industrial building stock are among the more transparent assets governed under professional environmental assessment, industry practice, and regulatory frameworks. Moreover, in most developed economies, residential properties are strongly linked to their community contexts. For example, neighborhood effects and local council planning regulations can strongly influence residential properties. Therefore, when separating the residential real estate asset as an asset holding option, it is unsurprising to find it performs better in the social CSR performance than other real estate asset types. The indifference of CSR governance performance across real estate asset types can be explained by the institutional (regulatory) rigidity of REITs corporate structure, legal requirements of company law, and capital market regulations. This is especially the case in the analysis when country and time effects are controlled.

The significant negative correlations of the hotel and hospital REITs asset type to their overall CSR scores correspond to their asset-specific characteristics and functionality being capital- and labor-intensive, hence their social costs. The 'different' relations between some real estate asset types, such as retail and industrial, are likely to correspond to significant heterogeneity within each asset type. For example, industrial properties involve various buildings and services depending on their specific production technology and product needs. It helps justify their indifference across the CSR dimensions. Given the highly diverse retail service types, the same logic applies to the retail assets hence Retail-REITs. At this stage, it is important to highlight that we are using composite data from MSCI and REITs and do not have access to the specifics of REITs holdings within each category, for example, hotels, to map the age of the real estate stock, which is likely to impact the ultimate ES\&G score. Further, we anticipate that REITs operating in different jurisdictions would have their CSR activity influenced by the legislative framework in these jurisdictions, a matter for further research. Thus, further granular analysis of country-level REITs is required to analyze local variations in CSR activity worldwide. 
Another contribution to the literature is the mapping of the impact of REITs' financial aspirations on their CSR scores, considering the real estate asset type holdings. Firms specializing in different real estate assets exhibit varying CSR responses to the REITs ${ }^{\prime}$ financial aspiration, showing different ranking orders in their portfolio asset management practice. We found that improved performance related to financial aspiration results in improved environmental scores for REITs holding hotels and inconsistently across the other types of real estate holdings. Thus, financial aspiration does not seem to have a uniformly positive impact on REITs' ES\&G scores, unlike in other industries. This is unexpected and requires unpacking with future research. Future research could perhaps focus on changes in the ES\&G CSR pillars separately for real-estate asset types in response to changes in legislative frameworks and other external shocks such as the current pandemic and new technology. The institutional investor's role in supporting socially responsible investment and the operation of real estate assets is an emerging area that equally deserves industry attention and research innovation.

Our findings will be of value to REITs looking to improve their ESG scores by highlighting the type of asset requiring more input and modification. REITs should realize that, unlike other industries, positive financial aspiration scores have not resulted in a concomitant increase in their CSR. Secondly, our findings can help investors understand the reasons for REITs CSR scores and focus on the quality and nature of the real estate holding and the corresponding ESG score, rather than the raw ESG scores. Thirdly, our research can help developers and builders to understand the importance of improving ESG scores for assets such as hotels to match offices and residential real estate. Finally, our research can help policymakers make appropriate soft and hard regulations for different real-estate types and perhaps revisit the lack of improved ESG scores with positive financial aspiration in this industry.

Author Contributions: All authors declare that they have made an equal and substantial contribution to this paper Conceptualization: J.L., A.J., H.W.; Literature Review: A.J., H.W.; Methodology: J.L., A.J.; Software and Validation: J.L.; Data Collection: J.L.; Writing and Review: A.J., H.W., J.L. We agree that we personally are accountable for our own contributions and will ensure that questions related to the accuracy or integrity of any part of the work, even ones in which we were not personally involved, are appropriately investigated, resolved, and documented in the literature. All authors have read and agreed to the published version of the manuscript.

Funding: This research receives no funding.

Institutional Review Board Statement: Not applicable.

Informed Consent Statement: Not applicable.

Data Availability Statement: The ESG data for this research is available from MSCI. The financial data is available from Compustat-Capital IQ, and the REIT property portfolio data can be found in REIT annual reports (available on their websites). The final database used to support the findings of this study are available from the corresponding author upon request.

Acknowledgments: We thank the anonymous reviewers for their valuable comments that have helped improve the paper.

Conflicts of Interest: The authors declare no conflict of interest.

\section{References}

1. Carroll, A.B. A three-dimensional conceptual model of corporate performance. Acad. Manag. Rev. 1979, 4, 497-505. [CrossRef]

2. Liang, H.; Renneboog, L. On the foundations of corporate social responsibility. J. Financ. 2017, 72, 853-910. [CrossRef]

3. Nareit. REITs by Numbers. Available online: https://www.reit.com/data-research/data/reits-numbers (accessed on 19 December 2020).

4. Bauer, R.; Eichholtz, P.; Kok, N. Corporate governance and performance: The REIT effect. Real Estate Econ. 2010, 38, 1-29. [CrossRef]

5. Brounen, D.; Marcato, G. Sustainable Insights in Public Real Estate Performance: ESG Scores and Effects in REIT Markets; Berkeley Laboratory: Berkeley, CA, USA, 2018. 
6. Campbell, R.D.; Ghosh, C.; Petrova, M.; Sirmans, C. Corporate governance and performance in the market for corporate control: The case of REITs. J. Real Estate Financ. Econ. 2011, 42, 451-480. [CrossRef]

7. Ho, K.H.; Rengarajan, S.; Lum, Y.H. “Green” buildings and Real Estate Investment Trust's (REIT) performance. J. Prop. Investig. Financ. 2013, 31, 545-574.

8. Sah, V.; Miller, N.; Ghosh, B. Are green REITs valued more? J. Real Estate Portf. Manag. 2013, 19, 169-177. [CrossRef]

9. Newell, G.; Lee, C.L. Influence of the corporate social responsibility factors and financial factors on REIT performance in Australia. J. Prop. Investig. Financ. 2012, 30, 389-403. [CrossRef]

10. Chiang, K.C.; Wachtel, G.J.; Zhou, X. Corporate social responsibility and growth opportunity: The case of real estate investment trusts. J. Bus. Ethics 2019, 155, 463-478. [CrossRef]

11. Balasubramanian, S.; Shukla, V.; Mangla, S.; Chanchaichujit, J. Do firm characteristics affect environmental sustainability? A literature review-based assessment. Bus. Strategy Environ. 2020, 30, 1389-1416. [CrossRef]

12. Allen, M.T.; Madura, J.; Springer, T.M. REIT characteristics and the sensitivity of REIT returns. J. Real Estate Financ. Econ. 2000, 21, 141-152. [CrossRef]

13. Benefield, J.D.; Anderson, R.I.; Zumpano, L.V. Performance differences in property-type diversified versus specialized real estate investment trusts (REITs). Rev. Financ. Econ. 2009, 18, 70-79. [CrossRef]

14. Islam, M.A.; Jain, A.; Thomson, D. Does GRI Influence Sustainability Disclosures in Asia-Pacific Banks? Australas. J. Environ. Manag. 2016, 23, 298-313. [CrossRef]

15. Gamerschlag, R.; Möller, K.; Verbeeten, F. Determinants of voluntary CSR disclosure: Empirical evidence from Germany. Rev. Manag. Sci. 2011, 5, 233-262. [CrossRef]

16. Chauvey, J.-N.; Giordano-Spring, S.; Cho, C.H.; Patten, D.M. The normativity and legitimacy of CSR disclosure: Evidence from France. J. Bus. Ethics 2015, 130, 789-803. [CrossRef]

17. Gjølberg, M. Explaining regulatory preferences: CSR, soft law, or hard law? Insights from a survey of Nordic pioneers in CSR. Bus. Politics 2011, 13, 1-31. [CrossRef]

18. Wang, X.; Cao, F.; Ye, K. Mandatory corporate social responsibility (CSR) reporting and financial reporting quality: Evidence from a quasi-natural experiment. J. Bus. Ethics 2018, 152, 253-274. [CrossRef]

19. Kim, M.; Kim, T. When Do CEOs Engage in CSR Activities? Performance Feedback, CEO Ownership, and CSR. Sustainability 2020, 12, 8195. [CrossRef]

20. Perez-Batres, L.A.; Doh, J.P.; Miller, V.V.; Pisani, M.J. Stakeholder pressures as determinants of CSR strategic choice: Why do firms choose symbolic versus substantive self-regulatory codes of conduct? J. Bus. Ethics 2012, 110, 157-172. [CrossRef]

21. Jain, A.; Kansal, M.; Joshi, M.; Taneja, P. Is the Indian corporate social responsibility law working for the public sector? Public Money Manag. 2021, 1-10. [CrossRef]

22. Cavaco, S.; Crifo, P. CSR and financial performance: Complementarity between environmental, social and business behaviours. Appl. Econ. 2014, 46, 3323-3338. [CrossRef]

23. Torugsa, N.A.; O'Donohue, W.; Hecker, R. Proactive CSR: An empirical analysis of the role of its economic, social and environmental dimensions on the association between capabilities and performance. J. Bus. Ethics 2013, 115, 383-402. [CrossRef]

24. Liao, Z.; Liu, Y. What drives environmental innovation? A meta-analysis. Bus. Strategy Environ. 2021, 30, 1852-1864. [CrossRef]

25. Bacinello, E.; Tontini, G.; Alberton, A. Influence of corporate social responsibility on sustainable practices of small and mediumsized enterprises: Implications on business performance. Corp. Soc. Responsib. Environ. Manag. 2021, 28, 776-785. [CrossRef]

26. Esparza Aguilar, J.L.; Reyes Fong, T. Practices of corporate social responsability developed by mexican family businesses and their impact on competitive success and innovation. Tec Empresarial 2019, 13, 45-57.

27. Briones Peñalver, A.J.; Bernal Conesa, J.A.; de Nieves Nieto, C. Analysis of corporate social responsibility in Spanish agribusiness and its influence on innovation and performance. Corp. Soc. Responsib. Environ. Manag. 2018, 25, 182-193. [CrossRef]

28. Muttakin, M.B.; Khan, A.; Subramaniam, N. Firm characteristics, board diversity and corporate social responsibility: Evidence from Bangladesh. Pac. Account. Rev. 2015, 27, 353-372. [CrossRef]

29. Chang, Y.; Lee, S.; Oh, W.Y. Approaching gain or avoiding loss? The impact of CEO regulatory focus and dynamism on CSR. Acad. Manag. Proc. 2018, 2018, 13635. [CrossRef]

30. TM, A.; Kaur, P.; Ferraris, A.; Dhir, A. What motivates the adoption of green restaurant products and services? A systematic review and future research agenda. Bus. Strategy Environ. 2021, 30, 2224-2240.

31. Mount, M.P.; Baer, M. CEO regulatory focus and risk-taking when firms perform below and above the bar. J. Manag. 2021. [CrossRef]

32. Rapson, D.; Shiers, D.; Roberts, C.; Keeping, M. Socially responsible property investment (SRPI). J. Prop. Investig. Financ. 2007, 25, 342-358. [CrossRef]

33. Campbell, J.L. Why would corporations behave in socially responsible ways? An institutional theory of corporate social responsibility. Acad. Manag. Rev. 2007, 32, 946-967. [CrossRef]

34. Bianco, C.; Ghosh, C.; Sirmans, C. The impact of corporate governance on the performance of REITs. J. Portf. Manag. 2007, 33, 175-191. [CrossRef]

35. Hartzell, J.C.; Sun, L.; Titman, S. The effect of corporate governance on investment: Evidence from real estate investment trusts. Real Estate Econ. 2006, 34, 343-376. [CrossRef] 
36. Newell, G.; Wen Peng, H.; Yam, S. Assessing the Linkages between Corporate Social Esponsibility and A-Reit Performance. Pac. Rim Prop. Res. J. 2011, 17, 370-387. [CrossRef]

37. Westermann, S.; Niblock, S.; Kortt, M. Corporate social responsibility and the performance of Australian REITs: A rolling regression approach. J. Asset Manag. 2018, 19, 222-234. [CrossRef]

38. Eichholtz, P.; Kok, N.; Yonder, E. Portfolio greenness and the financial performance of REITs. J. Int. Money Financ. 2012, 31, 1911-1929. [CrossRef]

39. Schleich, H.; Lindholm, A.; Falkenbach, H. Environmental Sustainability drivers for the real estate investor. In Proceedings of the 16th Annual European Real Estate Society (ERES) Conference, Stockholm, Sweden, 24-27 June 2009.

40. Lützkendorf, T.; Lorenz, D. Sustainable property investment: Valuing sustainable buildings through property performance assessment. Build. Res. Inf. 2005, 33, 212-234. [CrossRef]

41. Pivo, G.; Fisher, J. Investment Returns from Responsible Property Investments: Energy Efficient, Transit-Oriented and Urban Regeneration Office Properties in the US from 1998-2007; Working Paper WP-08-2. 2009. Available online: http:// reconnectingamerica.org/assets/Uploads/2008pivofisher.pdf (accessed on 25 May 2021).

42. Wilkinson, S.; Thompson, B.; Ke, Q. Whether environmental factors matter: Some evidence from UK property companies. J. Corp. Real Estate 2012, 14, 7-20.

43. Eichholtz, P.; Holtermans, R.; Kok, N.; Yönder, E. Environmental performance and the cost of debt: Evidence from commercial mortgages and REIT bonds. J. Bank. Financ. 2019, 102, 19-32. [CrossRef]

44. Hou, H.; Wu, H. Tourists' perceptions of green building design and their intention of staying in green hotel. Tour. Hosp. Res. 2021, 21, 115-128. [CrossRef]

45. MSCI. ESG Ratings Methodology. Available online: https://www.msci.com/our-solutions/esg-investing/esg-ratings (accessed on 3 December 2019).

46. Kolk, A. Sustainability, accountability and corporate governance: Exploring multinationals' reporting practices. Bus. Strategy Environ. 2008, 17, 1-15. [CrossRef]

47. Dempsey, N.; Bramley, G.; Power, S.; Brown, C. The social dimension of sustainable development: Defining urban social sustainability. Sustain. Dev. 2011, 19, 289-300. [CrossRef]

48. Orlitzky, M.; Siegel, D.S.; Waldman, D.A. Strategic corporate social responsibility and environmental sustainability. Bus. Soc. 2011, 50, 6-27. [CrossRef]

49. Massey, D.B.; Catalano, A. Capital and Land: Landownership by Capital in Great Britain; Edward Arnold: London, UK, 1978.

50. DiPasquale, D.; Wheaton, W. Urban Economics and Real Estate Markets; Prentice Hall: New York, NY, USA, 1996.

51. Wu, H.; Crawford, R.; Warren-Myers, G.; Dave, D.; Noguchi, M. The economic value of low-energy housing. Pac. Rim Prop. Res. J. 2016, 22, 45-58. [CrossRef]

52. Young, M.; Markham, F. Tourism, capital, and the commodification of place. Prog. Hum. Geogr. 2020, 44, 276-296. [CrossRef]

53. Ward, F.A.; Michelsen, A. The economic value of water in agriculture: Concepts and policy applications. Water Policy 2002, 4 , 423-446. [CrossRef]

54. Power, G.J.; Turvey, C.G. US rural land value bubbles. Appl. Econ. Lett. 2010, 17, 649-656. [CrossRef]

55. Atkeson, A. What Will Be the Economic Impact of COVID-19 in the US? Rough Estimates of Disease Scenarios; National Bureau of Economic Research: Cambridge, MA, USA, 2020.

56. Okafor, A.; Adusei, M.; Adeleye, B.N. Corporate social responsibility and financial performance: Evidence from US tech firms. J. Clean. Prod. 2021, 292, 126078. [CrossRef]

57. Beck, C.; Frost, G.; Jones, S. CSR disclosure and financial performance revisited: A cross-country analysis. Aust. J. Manag. 2018, 43, 517-537. [CrossRef]

58. Hou, T.C.T. The relationship between corporate social responsibility and sustainable financial performance: Firm-level evidence from Taiwan. Corp. Soc. Responsib. Environ. Manag. 2019, 26, 19-28. [CrossRef]

59. Cyert, R.M.; March, J.G. A Behavioral Theory of the Firm; Prentice-Hall: Englewood Cliffs, NJ, USA, 1963.

60. Greve, H.R. A behavioral theory of R\&D expenditures and innovations: Evidence from shipbuilding. Acad. Manag. J. 2003, 46, 685-702.

61. Rudy, B.C.; Johnson, A.F. Performance, aspirations, and market versus nonmarket investment. J. Manag. 2016, 42, 936-995. [CrossRef]

62. Liu, Y.; Lei, L.; Buttner, E.H. Establishing the boundary conditions for female board directors' influence on firm performance through CSR. J. Bus. Res. 2020, 121, 112-120. [CrossRef]

63. Lopatta, K.; Jaeschke, R.; Chen, C. Stakeholder engagement and corporate social responsibility (CSR) performance: International evidence. Corp. Soc. Responsib. Environ. Manag. 2017, 24, 199-209. [CrossRef]

64. Kim, J.; Chung, S.; Park, C. Corporate social responsibility and financial performance: The impact of the MSCI ESG ratings on Korean firms. J. Korea Acad. Ind. Coop. Soc. 2013, 14, 5586-5593.

65. Peillex, J.; Boubaker, S.; Comyns, B. Does It Pay to Invest in Japanese Women? Evidence from the MSCI Japan Empowering Women Index. J. Bus. Ethics 2019, 170, 595-613. [CrossRef]

66. Marsat, S.; Williams, B. CSR and market valuation: International evidence. Bank. Mark. Investig. Acad. Prof. Rev. 2013, 123, 29-42. [CrossRef] 
67. Hijjawi, M.; Lee, C.L.; Marzuki, J. CEO Overconfidence and Corporate Governance in Affecting Australian Listed Construction and Property Firms' Trading Activity. Sustainability 2021, 13, 10920. [CrossRef]

68. Liang, J.; Dong, Z. Property portfolio composition and earnings management for listed property portfolios. J. Real Estate Lit. 2014, 20, 111-124.

69. Liang, J.; Dong, Z. The impact of the stapled security structure on the quality of financial disclosure: Evidence from Australian Real Estate Investment Trusts and Listed Infrastructure Funds. J. Contemp. Account. Econ. 2019, 15, 206-223. [CrossRef]

70. Liang, J.J.; Dong, Z. How the 2007 global financial crisis changed the financial disclosure behavior: The case of US equity REITs. Prop. Manag. 2018, 36, 156-172. [CrossRef]

71. Audia, P.G.; Greve, H.R. Less likely to fail: Low performance, firm size, and factory expansion in the shipbuilding industry. Manag. Sci. 2006, 52, 83-94. [CrossRef]

72. Greve, H.R. Investment and the behavioral theory of the firm: Evidence from shipbuilding. Ind. Corp. Chang. 2003, 12, 1051-1076. [CrossRef] 